\title{
STREOTIPE GENDER DAN PILIHAN KAREER DI KALANGAN SISWI MADRASAH ALIYAH (MA) DINIYAH PUTERI PEKANBARU RIAU
}

\author{
Riswani \\ Dosen Fakultas Tarbiyah dan Keguruan UIN Suska Riau
}

\author{
Hermansyah \\ Dosen Fakultas Ilmu Budaya Universitas Lancang Kuning Pekanbaru
}

\begin{abstract}
This study is a descriptive research in the form of a survey of 50 female students of Madrasah Aliyah. It disclosed is whether the students know that men and women can not be distinguished by the characters and roles, career what they would choose if already left school and what form career guidance given by the counseling teacher to reduce the attitude of gender stereotypes in students career choices. The results showed students know that men and women can not be distinguished by the character and role. Then, there are students who choose a job that is considered masculine and feminine as a future career. Student knows that men and women can not be distinguished by the character and role when they received material about gender in career information services provided by counseling teacher. The researchers concluded that gender stereotypes in students career choices can be minimized through the perspective of career guidance services. Researchers suggest there should be a gender perspective in the training of career guidance in Islamic schools.
\end{abstract}

Keywords: gender stereotypes, career counseling, counseling teacher.

Abstrak: Penelitian ini merupakan penelitian deskreptif dalam bentuk survey terhadap 50 orang siswi madrasah Aliyah. Hal yang diungkapkan adalah apakah siswa mengetahui bahwa laki-laki dan perempuan tidak bisa dibedakan melalui karakter dan peran, karir apa yang akan mereka pilih jika sudah tamat sekolah dan bagaimana bentuk bimbingan karir yang diberikan oleh Guru BK/Konselor untuk mengurangi sikap stereotip gender dalam pilihan karir siswa. Hasil penelitian menunjukkan siswa mengetahui bahwa laki-laki dan perempuan tidak bisa dibedakan melalui karakter dan peran. Kemudian, ada siswa yang memilih pekerjaan yang dianggap maskulin dan feminin sabagai karir dimasa depan. Siswi mengetahui bahwa laki-laki dan perempuan tidak bisa dibedakan melalui karakter dan peran ketika mereka mendapat materi tentang gender dalam layanan informasi karir yang diberikan oleh Guru BK/Konselor. Peneliti menyimpulkan bahwa streotif gender di dalam pilihan karir siswa dapat diminimalisir melalui layanan bimbingan karir yang berperspektif. Peneliti menyarankan harus ada pelatihan bimbingan karir berperspektif gender di sekolah-sekolah Islam.

Kata Kunci: Stereotip Gender, Bimbingn Karir, Guru BK/Konselor

\section{PENDAHULUAN}

Hasil penelitian yang dilakukan oleh Bandura et al1 ${ }^{1}$ Cherian,2 Isaac and Nwalo3, Macgregor4, McMahon dan Watson ${ }^{5}$, Watson et al ${ }^{6}$ menunjukkan bahwa banyak siswa sekolah menengah atas (SMA/MA) menghadapi dilema ketika membuat keputusan pilihan karir dalam hidup mereka. Hal ini didukung oleh Denga yang menyebutkan bahwa memilih karir yang tepat adalah salah satu keputusan yang paling sulit yang dialami oleh seorang remaja laki-laki maupun perempuan. Nada yang sama 
juga dikatakan oleh Kinanee yang menyebutkan bahwa remaja menghadapi masalah yang paling kompleks saat terlibat dalam memilih kareer yang tepat dan realistis ${ }^{7}$.

Siswa SMA/MA secara psikologis sedang dalam perkembangan masa remaja, yakni masa peralihan dari masa kanak-kanak menuju dewasa. Menurut Hurlock $^{8}$ masa remaja merupakan masa yang sangat berhubungan pada penentuan kehidupan di masa depan, karena perilaku dan aktivitas yang dilakukan pada masa remaja menjadi masa awal dalam mengukir kehidupan yang lebih baik di masa depan mereka. Jadi, jika masa remaja mencapai perkembangan optimal maka bisa dipastikan masa depan seorang remaja akan berjalan dengan baik pula.

Masa remaja merupakan pencarian identitas diri. Ia harus mampu menjawab “Siapa saya? Mau ke mana saya? Bagaimana saya? Apa yang harus saya perbuat untuk karir masa depan saya?. Sejumlah pertanyaan identitas diri seyogyanya dapat dijawab dengan tepat oleh remaja. Jika ia tidak dapat menjawabnya dengan tepat maka ia cenderung bingung menghadapi hidup, termasuk pengambilan keputusan karir. Tetapi jika sebaliknya, maka ia akan berkembang optimal dan tepat dalam mengambil keputusan karirnya sehingga masa depan penuh dengan harapan ${ }^{9}$

Masa remaja juga merupakan masa dimana individu sudah mempersiapkan diri untuk berkarir. Namun pada kenyataannya banyak siswa yang belum mencapai kematangan karir dengan baik. Fenomena masa anak remaja sekarang ini masih banyak kita melihat banyak remaja menghabiskan waktunya dalam hal-hal yang tidak bermanfaat bagi dirinya dan bahkan melakukan hal-hal yang bisa merusak dirinya dan masa depannya. Seharusnya, ketika sudah duduk di bangku SMA/MA, remaja sudah mampu merencanakan dan mempersiapkan masa depannya yang lebih baik apa lagi di era globalisasi sekarang, dimana individu dituntut untuk lebih proaktif dalam merencanakan dan mempersiapkan masa depannya. Jika itu tidak dilakukan, maka reamaja maka akan tergilas oleh kejamnya zaman. Maka tidak mengherankan jika remaja sering mengeluhkan akan masa depannya, mereka tidak mengetahui mau jadi apa dan pekerjaan apa yang cocok baginya.

Yusuf10 menyebutkan bahwa terdapat permasalahan karir yang dialami oleh para remaja usia SMA, diantaranya: (1) kurang mengetahui cara memilih program studi; (2) kurang memiliki motivasi untuk mencari informasi tentang karir; (3) bingung dalam memilih pekerjaan; dan (4) belum memiliki pilihan 
perguruan tinggi tertentu jika setelah lulus. Sedangkan Supriatna ${ }^{11}$ mengemukakan masalah karir yang dirasakan oleh siswa, antara lain sebagai berikut: (a) siswa kurang memahami cara memilih program studi yang cocok dengan kemampuan dan minat; (b) siswa tidak memiliki informasi tentang dunia kerja yang cukup; (c) siswa masih bingung untuk memilih pekerjaan; (d) siswa masih kurang mampu memilih pekerjaan yang sesuai dengan kemampuan dan minat; (e) siswa merasa cemas untuk mendapat pekerjaan setelah tamat sekolah; (f) siswa belum memiliki pilihan perguruan tinggi atau lanjutan pendidikan tertentu, bila setelah tamat tidak masuk dunia kerja; (g) siswa belum memiliki gambaran tentang karakteristik, persyaratan, kemampuan, dan keterampilan yang dibutuhkan dalam pekerjaan, serta prospek pekerjaan untuk masa depan karirnya.

Beberapa teori pengembangan karir menyatakan bahwa stereotipe gender adalah salah satu faktor yang mempengaruhi pilihan karir. The Social Cognitive Theory Karir (SCCT) yang dikembangkan oleh BrownC. And M. Corcoran ${ }^{12}$, pada tahun 1987 menjelaskan bahwa pilihan karir dipengaruhi oleh perkembangan keyakinan individu yang diperoleh melalui proses pembelajaran. Melalui proses belajar, siswa dapat mengambil prasangka orang tua mereka dan anggota masyarakat lainnya. Misalnya, siswa yang orang tuanya mengatakan karir tertentu cocok untuk pria sementara yang lain hanya cocok untuk wanita dapat mengadopsi sikap seperti ini ke dalam diri mereka. Teori tipe kepribadian John Holland ${ }^{13}$ yang dikembangkan pada tahun 1959 yang bertumpu pada asumsi bahwa orang dapat dikategorikan dalam salah satu jenis karir berikut: realistis, investigasif, sosial, konvensional, giat dan artistik. Lent, R.W.,Brown, S. D., \& Hacket ${ }^{14}$ menemukan bahwa perempuan cenderung memiliki skor tinggi dalam seni, sosial dan pekerjaan konvensional, sedangkan pria lebih memungkinkan untuk memilih pekerjaan yang realistis, investigasi dan giat.

Terlepas dari teori yang digunakan untuk mengidentifikasi faktorfaktor yang mempengaruhi pilihan karir, stereotipe gender merupakan faktor penting yang harus diteliti untuk mengurangi perbedaan dalam karir antara laki-laki dan perempuan. Sebagaimana yang diungkapkan oleh O'Reilly et al bahwa kerjasama guru dan orang tua untuk mengurangi sikap dan perilaku yang mendukung perbedaan gender sangat dibutuhkan.

Pembahasan stereotip gender dalam pilihan karir di kalangan siswa 
akan menjadi menarik ketika hal tersebut berhubungan dengan sekolah/madrasah khusus puteri (single sex school) karena beberapa pendapat cenderung mengatakan bahwa sekolah khusus puteri berkontribusi terhadap ketidaksetaraan gender dalam pendidikan. Dukungan pendapat ini diperkuat oleh kenyataan bahwa salah satu misi dari sekolah/madrasah khusus puteri adalah mempersiapkan puteri "sejati" dimana kata "sejati" bisa diartikan mempersiapkan perempuan untuk mengerjakan pekerjaan-pekerjaan yang konvensional.

Stereotip gender merupakan cerminan dari cara pandang masyarakat yang selalu menempatkan sebuah entitas dalah hirarki hubungan baik relasi secara vertikal maupun horizontal (sintagmatik dan paradigmatik). Representasi perempuan dapat dilihat dari penempatan perempuan dalam relasi sosial dengan kaum laki-laki, dimana perempuan selalu menempati posisi subordinat laki-laki sebagai akibat dari budaya patriarki yang melingkupi masyarakat tersebut baik secara historis, kultural ataupun sosial.

Stereotip gender dari kerangka historis, dapat dilihat dari tiga aspek, yaitu biologis, psikologis, dan mitologis. Dari sisi biologis (fisik), perempuan secara fisik mempunyai kontur tubuh yang membuat mereka lebih sesuai untuk mengerjakan pekerjaan yang tidak terlalu mengandalkan tenaga (fisik) melainkan pekerjaan yang membutuhkan ketelatenan, rasa dan halus budi. Karena kontur fisik tersebut, secara psikologis, perempuan ditempatkan sebagai sosok yang lebih mengedepankan rasa atau emosi dalam bertindak, membutuhkan perlindungan, cenderung menghindar dari konfrontasi, dan serba lembut. Nilainilai di atas secara sengaja dijadikan sebagi sebuah konstruksi atau pola pikir yang dilembagakan dalam semua aspek kehidupan: hukum, politik, dan pranata sosial ${ }^{15}$.

Sebagai sebuah konstruksi sosial, sangat sulit untuk tidak mengiyakan jika cerminan bias gender sedemikian timpang dalam praktik keseharian. Ketidaksejajaran stereotip gender dapat dilihat dalam perlakuan masyarakat terhadap perempuan khususnya dalam pemilihan karir. Hal ini tercermin dalam beberapa contoh. Misalnya perempuan lebih emosional sehingga ia tidak cocok dengan bidang pekerjaan yang membutuhkan tenaga. Dalam buku ajar anak sekolah dasar masih sering dijumpai kalimat yang secara tidak langsung menunjukkan posisi dan peran perempuan di samping laki-laki. Kalimat Ibu sedang memasak di dapur dan Ayah sedang membaca koran di halaman hanyalah sebagian kecil dari praktek streotipe 
tersebut. Seakan kalimat tersebut ingin mengatakan kaum laki-laki berkecimpung umtuk pekerjaan yang di depan, sedangkan perempuan identik dengan pekerjaan belakang (subordinasi perempuan secara horisontal terhadap laki-laki) ${ }^{16}$.

Nilai dan norma yang berlaku dalam masyarakat secara efektif ditanamkan baik secara sadar atau tidak oleh komunitas sekitar. Pintu masuk awal pemerolahan fitur yang melekat pada sebuah entitas berawal pada saat manusia untuk pertama kalinya berinteraksi dengan komunitas sekitar terutama orang tua dan sekolah. Melalui orang tua dan sekolah, anak mempelajari konsep yang bermakna positif dan negatif, yang harus dianut dan tidak, dan yang disepakati oleh masyarakat sekeliling dan tidak.Pengenalan stereotip gender khususnya perempuan juga mendapatkan porsi yang sangat proporsional pada waktu anak mulai mengenal dunia sekitar melalui orang terdekat dan media pendukung lain. Stereotip yang terbangun akan demikian kuat melekat pada anak jika terjadi penguatan dan dukungan dari masyarakat sekeliling melalui nilai dan norma yang berlaku pada masyarakat tersebut.

Mengingat pentingnya masalah karir dalam kehidupan manusia, maka sejak dini seharusnya siswa sudah dipersiapkan dan dibantu untuk merencanakan tentang karirnya. Ketika duduk di bangku sekolah menegah, siswa sudah harus diperluas pandangannya bahwa pengotakan karir berdasarkan streotipe gender adalah sebuah konstruksi budaya yang dapat ditubah. Hal ini bisa dilakukan dengan cara memberikan pendidikan dan pemahaman orientasi karir yang berspektif gender. Siswa diberi pemahaman bahwa kebudayaan sebuah masyarakat mempertalikan peran kepada perempuan dan laki-laki di luar fungsi biologis mereka yang telah ditetapkan, dan peran ini terkadang membatasi pilihan-pilihan pekerjaan dan pendidikan seseorang.Siswa juga harus mendapat penjelasan bahwa aki-laki dan perempuan dapat dibedakan secara eksklusif oleh karakteristik yang berhubungan dengan kegiatan reproduktif. Melahirkan atau menyusui adalah contoh-contoh kegiatan reproduktif yang hanya dapat dilakukan oleh seorang perempuan.Gender berhubungan dengan karakteristik dan peran harus dianggap berasal dari seseorang oleh masyarakat/komunitas tertentu. Dalam masyarakat tradisional contohnya, perempuan diasosiasikan dengan kegiatan-kegiatan rumah tangga seperti memasak, mengasuh anak, menyiapkan makanan, atau menyapu rumah. Di sisi lain, laki-laki diasosiasikan dengan kegiatan kegiatan yang berkaitan 
dengan perlindungan keluarga dan kebutuhan-kebutuhan ekonomi. Kegiatankegiatan seperti bekerja untuk mendapatkan uang atau membuat keputusan lebih sering diasosiasikan dengan laki-laki. Dalam dunia kerja, orang mungkin merasa dibatasi dalam pilihan-pilihan mereka karena peran/karakteristik gender dalam masyarakat yang yang telah ditugaskan kepada mereka.

potensi, kesempatan pekerjaan dan jalur pendidikan yang bisa mereka ambil. Hal ini penting, mengingat remaja memiliki beberapa keterbatasan dalam pilihan mereka oleh a) gagasan yang ditanamkan oleh keluarga dan masyarakat akan apa yang dianggap sebagai pilihan pekerjaan dan pendidikan yang tepat $b$ ) kenyataan ekonomi yang sangat buruk yang menghambat mereka dalam mengikuti pendidikan yang mereka pilih, c) kurang akses akan fasilitas pendidikan. Karena itu, penting bagi guru BK untuk menyadari adanya keterbatasan tersebut dan mengakui batasan keterlibatannya dalam proses pengambilan keputusan ${ }^{17}$.

Penelitian ini mengungkapkan: (1) Apakah siswa mengetahui bahwa lakilaki dan perempuan tidak bisa dibedakan melalui karakter dan peran? (2) Karir apa yang akan mereka pilih jika sudah tamat sekolah? (3) Bagaimana bentuk bimbingan karir yang diberikan oleh guru konseling untuk mengurangi sikap stereotip gender dalam pilihan karir siswa? Disamping untuk mengetahui apakah siswa mengetahui bahwa laki-laki dan perempuan tidak bisa dibedakan melalui karakter dan peran dan karir apa yang akan mereka pilih jika sudah tamat sekolah, penelitian ini juga bertujuan untuk medeskripsikan bentuk bimbingan karir perspektif gender. Hasil penelitian

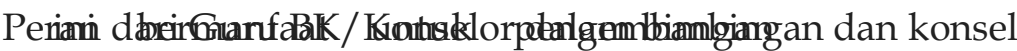
bimbingan karir berperspektif gender di sekolah dan madrasah.

\section{Stereotip Gender}

Nauly ${ }^{18}$ dalam menjelaskan streotip gender mengutip pendapaat beberapa pakar antra lain (1) Wrightdmrn yang mendefinisikan stereotip merupakan konsep yang relatif kaku dan luas di mana setiap individu di dalam suatu kelompok dicap dengan karakter dari kelompok tersebut. (2) Jenkins dan Mc Donald sepakat bahwa streotip peran gender merupakan generalisasi pengharapan mengenai aktivitas, kemampuan, atribut dan pilihan apa yang sesuai dengan jenis kelamin seseorang. (3) Hoyenga dan Hoyenga menjelaskan bahwa stereotip peran gender dihasilkan dari pengkategorisasian perempuan dan laki-laki, yang merupakan suatu representasi sosial yang ada dalam sturktur kognisi kita. Akhirnya stereotip gender digunakan untuk menggambarkan aspek aspek 
sosiologis/antropologis/kultural dari ciri atau sifat maskulin dan feminine. Namun, menurut (4) Vob Baeyer, Sherk dan Zanna stereotip gender pribadi yang dimiliki seseorang, dapat berbeda dari apa yang dimiliki atau diterapkan oleh kebanyakan orang di budayanya. Mungkin saja ada ketidaksesuaian antara perilaku seseorang dan peranperan stereotip yang digambarkan oleh budayanya tentang gender. Pemahaman seseorang akan perbedaan ini dapat mempengaruhi bagaimana ia menampilkan dan mengevaluasi dirinya.

Selanjutnya Nauly juga mengutip Baron dan Byrne bahwa stereotip gender merupakan sifat-sifat yang dianggap benar-benar dimiliki oleh perempuan dan laki-laki, yang memisahkan ke dua gender.Dari berbagai hasil penelitian Baron dan Byrne lebih lanjut menyimpulkan bahwa memang ada beberapa perbedaan perilaku sosial di antara perempuan dan laki-laki, seperti kemampuan memberi dan menerima pesan-pesan nonverbal serta agresivitas, tetapi besar dan keluasan perbedaan ini jauh lebih kecil dari apa yang diungkapkan oleh stereotip. Sayangnya, apa yang dikatakan Baron dan Byrne berbeda dari kenyataannya karena kebanyakan dari stereotip tersebut tidak akurat, namun tetap memberikan efek yang negatif, antara lain: mencegah perempuan mendapatkan pekerjaanpekerjaan tertentu, mencegah promosi tertentuk untuk perempuan serta menghambat perempuan mendapatkan upah yang sama dalam pekerjaannya.

Stereotip atau belief tentang peran laki-laki dan perempuan bukanlah merupakan prasangka. Stereotip ini bisa jadi akurat, tidak akurat atau generalisasi yang berlebihan, namun menurut Myers didasarkan atas setitik kebenaran.Studi lintas budaya tentang stereotip gender berdasar penelitian William \& Best di 30 negara yang berbeda, menemukan lakilaki cenderung dilihat lebih mandiri, lebih ekshibisionistik, lebih agresif, lebih dominan, lebih berorientasi sukses dan lebih tekun sedangkan perempuan dianggap lebih besar kebutuhannya untuk menghargai orang lain, perasaan bersalah, mendengarkan orang lain dan berhubungan dengan lawan jenis ${ }^{19}$.

Dalam Kamus Besar Bahasa Indonesiastereotip mempunyai makna (1) bentuk tetap; bentuk klise,(2) konsepsi mengenai sifat suatu golongan berdasar prasangka yang subjektif dan tidak tepat $^{20}$. Lips dalam Sex and Gender ${ }^{21}$ menjelaskan bahwa teori stereotip gender secara umum berusaha menjelaskan perbedaan dan persamaan antara laki-laki dan perempuan. Adapun teori tersebut ada lima. Pertama, teori psikoanalisis atau identifikasi (psichoanalytic/identification theory) yang memfokuskan pada pengembangan kepribadia (personality). 
Kedua, teori struktur sosial (social structural theory). Teori ini berusaha mencari jawaban bagaimana hubungan antara peran gender laki-laki dan perempuan dan stereotip di antara keduanya dilihat dari struktur sosial dan kultural. Teori ketiga adalah sosiobiologi yang berusaha menjelaskan isu-isu gender dengan mengacu pada evolusi spesies manusia. Ketiga teori tersebut menekankan pada asal muasal jender, mengapa jenis kelamin dibedakan. Sedangkan dua teori yang lain yaitu pembelajaran sosial (social learning) dan pengembangan kognitif (cognitive development) lebih memfokuskan pada bagaimana perbedaan gender muncul dan bagaiamana laki-laki dan perempuan mengadopsi kelakuan (behaving).

Kweldju sebagaimana yang dikutip oleh Oktiva Herry ${ }^{22}$ menjelaskan bahwa stereotip seks merupakan seperangkat keyakinan yang telah terstruktur melalui penyederhanaan atribut pribadi laki-laki dan perempuan. Karena atribut ini merupakan penyederhanaan maka sering tidak sesuai dengan keadaan yang sebenarnya. Atribut ini berupa ciri-ciri kepribadian, fisik, dan tingkah laku yang dikehendaki oleh masyarakat.Karena stereotip merupakan sesuatu yang dikehendaki masyarakat, sedangkan masyarakat selalu berubah, maka stereotip pun bersifat dinamis sesuai dengan harapan masyarakat tersebut.

Dalam penelitian stereotip seks, pada umumnya digunakan tiga pendekatan yaitu psikodinamik, kognitif, dan sosiokultural. Pendekatan psikodinamik untuk mengkaji asal-usul lahirnya stereotip seks berdasar teori psikologi perkembangan. Sedangkan penelitian kognitif dipergunakan untuk mengkaji bagaimana manusia belajar memperoleh stereotip seks sejak mulai lahir serta bagaimana pengaruh stereotipe seks tersebut berpengaruh terhadap kemampuan kognitifnya. Sedangkan pendekatan yang terakhir, sosiokultural, merupakan pendekatan yang biasa dipergunakan dalam studi stereotip seks dalam bahasa.

Stereotip terbentuk dari beberapa aspek yaitu sejarah, asal kelas dan kultur sebagaimana yang dikutip oleh Oktiva Hary dari Wijaya ${ }^{23}$. Sejarah menunjukkan bahwa perempuan mempunyai ketergantungan terhadap laki-laki karena perempuan secara kontekstual ditempatkan pada karakteristik yang khas perempuan, seperti suka perlindungan laki-laki, rasa ketergantungan yang besar terhadap pihak lain, khususnya laki-laki. Perempuan yang berasal dari kelas sosial tertentu akan mempunyai karakteristik tertentu yang berbeda dari karakteristik perempuan kelas sosial yang berbeda. Hal 
ini merupakan latar belakang stereotip perempuan dari aspek asal kelas. Kultur laki-laki yang dominan di satu pihak, dan perempauan di pihak tersubordinasi akan membentuk stereotip perempuan yang bersifat subordinat terhadap laki-laki.

Adapun stereotip perempuan yang bersifat positif diantaranya adalah tidak suka menggunakan kata-kata kotor, suka berbicara, berbicara pelan, mudah mengekspresikan perasaan dan lain-lain. Sedangkan stereotip perempuan yang bersifat negatif adalah tergantung, tidak agresif, sangat emosional, sangat mudah dipengaruhi, berbelit-belit, tidak ambisius, tidak bebas berbicara seks dengan lakilaki, dan sebagainya. Namun, apabila stereotip perempuan yang bersifat positif dan negatif diperbandingkan, maka lebih banyak stereotip yang bersifat negatif.

Teori-teori tentang stereotip ini telah mengalami perubahan selama 20 tahunterakhir. Bila tadinya stereotip dianggap suatu bentuk patologi, kini dianggap sebagai konsekuensi inheren dari kecenderungan manusia untuk mengelompokkan sesuatu, melalui proses kategorisasi. Stereotip ini meringkas dan mengorganisasikan apa yang telah dipelajari seseorang tentang kelompokkelompok social.

Streotip dapat bermuatan positif, negatif atau netral. Stereotip yang negatif dapat berubah menjadi prasangka.
Banyak dari penemuan-penemuan teoritis maupun praktis mengenai stereotip, diperoleh dari kenyataan bahwa kebanyakan dari kelompok yang menjadi target stereotip negatif tertentu, juga menjadi target prasangka dan perilaku diskriminasi, yang berkaitan dengan stereotip itu. Dapat dikatakan pada kasuskasus seperti ini, stereotip negatif diekspresikan melalui prasangka dan perilaku diskriminasi24. Prasangka terhadap kelompok ras tertentu disebut sebagai rasisme, sedangkan prasangka terhadap jenis kelamin tertentu disebut seksisme.

\section{Faktor Penguat Stereotip Gender}

Oktiva Herry ${ }^{25}$ menjelaskan bahwa konstruksi sosial yang terbangun dalam masyarakat merupakan konstruksi yang diwariskan pada generasi selanjutnya melalui mekanisme pemberian stimulan dan penguatan (reinforcement). Penguatan ini dilakukan dalam dua cara, yaitu langsung dan tidak langsung. Penguatan dilakukan secara sengaja jika secara sadar lingkungan sekitar menanamkan strereotip gender tertentu pada anak. Dari hasil wawancara dan pengamatan, mekanisme penguatan ini dilakukan oleh orang di rumah, luar rumah, dan sekolah.

Penguatan di rumah biasanya 
dilakukan oleh anggota keluarga, seperti ayah dan ibu, kakak atau adik, kakek dan nenek, dan saudara. Penguatan ini biasanya dilakukan dengan cara pemberitahuan pada hal yang tepat terhadap perilaku tertentu. Misalnya, seorang anak laki-laki, ditegur oleh ibunya karena tidak mau membantu membetulkan sepeda kakaknya yang perempuan dengan mengatakan bahwa dia harus membetulkan sepeda itu karena dia laki-laki di rumah itu. Sebaliknya, anak perempuan pernah ditegur oleh ibunya untuk tidak memanjat pohon mangga yang ada di rumah tetangga, karena memanjat pohon tidak baik untuk dilakukan oleh kaum perempuan.

Penguatan sejenis juga terjadi di luar lingkungan keluarga. Teman sepermainan relatif dominan dalam proses penguatan ini. Teman-teman permainan baik di sekolah ataupun di rumah sering kali memberikan pernyataan yang secara tidak langsung membedakan beberapa kegiatan yang dapat dilakukan oleh seorang laki-laki dan perempuan. Mereka dengan sendirinya sudah memilah-milah kegiatan tersebut sesuai dengan konstruksi atau konsep dari keluarga masing-masing. Bisa dipastikan semua anak mempunyai konstruksi sosial yang sama. Jenis permainan yang dikerjakan, misalnya, sudah menunjukkan adanya pemilahan dua jenis kelamin ini. Anak laki-laki cenderung melakukan kegiatan yang bersifat outdoor, seperti bermain sepak bola, layang-layang, mencari ikan, main kelereng, dan mereka sangat tidak suka jika harus bermain jenis permainan indoor, seperti bermain masak-masakan, sekolahsekolahan, permainan yang dimainkan anak perempuan adalah permainan khas anak-anak perempuan. Kadang terjadi anak perempuan menyuruh anak laki-laki untuk tidak ikut dalam permainan mereka dengan menyebutkan kategori permainan tersebut.Penguatan ini berlanjut pada anak usia remaja ketika akan memilih ekstrakurikuler, dan pada akhirnya ketika mereka akan memilih karir yang akan mereka jadikan sebagai pekerjaan.

Media masa, terutama televisi, juga ikut mempengaruhi konsep anak terhadap pemilahan dunia laki-laki dan perempuan. Tayangan iklan dalam televisi, sebenarnya, dapat dikategorikan ke dalam tiga kelompok besar, yaitu iklan yang mempertontonkan kegiatan yang biasa dilakukan kaum perempuan, kegiatan yang biasa dilakukan oleh lakilaki dan iklan yang berlaku untuk semua jenis kelamin. Produk rumah tangga atau domestik seperti iklan sabun pewangi, susu untuk ibu yang hamil dan beberapa jenis ilkan lain mempertontonkan pada anak-anak adanya wilyah tertentu yang hanya bisa dan boleh dilakukan oleh 
kaum perempuan. Aspek visual yang ditampilkan juga sangat mendorong anak untuk berpikiran bahwa iklan itu hanya ditujukan untuk kaum perempuan karena figur yang muncul dalam iklan tersebut biasanya hanya kaum Ibu dan anak perempuannya. Di sudut lain, misalnya dalam iklan susu Milo, anak laki-laki dengan jenis permainan sepak bola sangat memberi kesan iklan itu adalah untuk laki-laki, apalagi ditopang visual di mana sang Ibu mendukung sepenuhnya kegiatan tersebut dan ditempatkan pada posisi sebagai orang yang harus menyediakan dan mempersiapkan susu pada anak laki-lakinya. Di sini, pemilahan Ibu sebagai orang yang bertanggung jawab dalam penyediaan domestik untuk anaknya, dan anak laki-laki yang mesti dilayani oleh Ibu yang merepresentasikan kaum perempuan berada pada penyedia dan pelayan yang baik nampak jelas terlihat. Dampak yang dihasilkan adalah persepsi anak pada dunia tertentu yang masuk tiga kategori di atas semakin diasah dan semakin tajam. Internalisasi yang demikian ini sangat sering ditami oleh-anak-anak mengingat media, baik cetak maupun tertulis, sangat akrab dengan mereka.

\section{Karir}

Super dalam Dewa Ketut Sukardi menyebutkan karir suatu suatu rangkaian pekerjaan-pekerjaan, jabatan-jabatan, dan kedudukan yang mengarah pada kehidupan dalam dunia kerja ${ }^{26}$. Karir adalah semua pekerjaan atau jabatan yang ditangani atau dipegang selama kehidupan kerja seseorang27. Menurut Gibson dkk, karir adalah rangkaian sikap dan perilaku yang berkaitan dengan pengalaman dan aktivitas kerja selama rentang waktu kehidupan seseorang dan rangkaian aktivitas kerja yang terus berkelanjutan ${ }^{28}$.

Menurut Gould ${ }^{29} \quad$ karir merupakan urutan posisi yang terkait dengan pekerjaan yang diduduki seseorang sepanjang hidupnya. Karir adalah sebagai pola pengalaman berdasarkan pekerjaan (work-related experiences) yang merentang sepanjang perjalanan pekerjaan yang dialami oleh setiap individu/pegawai dan secara luas dapat dirinci ke dalam obyective even.

$$
\text { Greenhaus }{ }^{30} \text { menyebutkan }
$$

terdapat dua pendekatan untuk memahami makna karir, yaitu : pendekatan pertama memandang karir sebagai pemilikan (a property) dan/atau dari occupation atau organisasi. Pendekatan ini memandang bahwa karir sebagai jalur mobilitas di dalam organisasi yang tunggal seperti jalur karir di dalam fungsi marketing, yaitu menjadi sales representative, manajer produk, 
manajer marketing distrik, manajer marketing regional, dan wakil presiden divisional marketing dengan berbagai macam tugas dan fungsi pada setiap jabatan. Pendekatan kedua memandang karir sebagai suatu properti atau kualitas individual dan bukan occupation atau organisasi. Pendekatan ini memandang bahwa karir merupakan perubahanperubahan nilai, sikap, dan motivasi yang terjadi pada setiap individu/pegawai. Berdasarkan kedua pendekatan tersebut definisi karir adalah sebagai pola pengalaman berdasarkan pekerjaan (workrelated experiences) yang merentang sepanjang perjalanan pekerjaan yang dialami oleh setiap individu/pegawai dan secara luas dapat dirinci ke dalam obyective events. Salah satu contoh untuk menjelaskannya melalui serangkaian posisi jabatan/pekerjaan, tugas atau kegiatan pekerjaan, dan keputusan yang berkaitan dengan pekerjaan (workrelated decisions).

Dari berbagai pendapat di atas, dapat disimpulkan bahwa karir adalah suatu status atau jenjang pekerjaan atau jabatan seseorang sebagai sumber nafkah apakah itu sebagai pekerjaan utama maupun pekerjaan sambilan.

\section{Teori-Teori Perkembangan Karir}

Menurut Sunardi ${ }^{31}$ untuk lebih memahami hakekat karir, karir dapat ditinjau dari teori-teori perkembangan karir yang dikemukakan oleh para ahli, diantaranya Gibson dan Mitchell yang membagi kepada lima teori perkembangan karir, yaitu : (1) teori proses, (2) teori perkembangan, (3) teori kepribadian, (4) teori sosiologi, (5) teori ekonomi, dan (6) teori lain. Selanjutnya Sunardi menjelaskan teori-teori tersebut sebagai berikut:

\section{Teori Proses}

Teori proses menyebutkan, pilihan pekerjaan dan akhirnya masuk dalam suatu pekerjaan tertentu sesuai pilihan adalah proses yang berisi tahapantahapan tertentu yang akan dilalui oleh setiap individu. Salah satu tokoh teori proses adalah Ginzberg. Menurut Ginzberg, perkembangan karir terikat pada tiga eleman dasar, yaitu proses, iveribilitas, dan kompromi. Ditinjau dari elemen proses, pengambilan keputusan karir berlangsung melalui tiga periode, yaitu fantasi, tentatif, dan realistik. Pada periode fantasi pemilihan pekerjaan dilakukan tanpa memperhitungkan tuntutan realitas, asal-asalan. Periode tentatif terdiri fase: minat, kapasitas, nilai, dan transisi. Artinya pertama berdasar pada minat/kesukaannya, kemudian mulai mempertimbangkan kemampuannya, diikuti dengan 
didasarkan tujuan dan nilai yang mendasari, dan terakhir dilakukan dengan memperhitungkan realitas. Sedangkan periode realistik terbagi atas fase eksplorasi, kristalisasi, dan spesifikasi. Artinya, setelah anak melakukan eksplorasi dan dengan memadukan faktor-faktor internal dan eksternal, selanjutnya anak memasuki fase kristaliasi dengan mengambil keputusan, dan selanjutnya mengambil keputusan yang lebih spesifik. Berdasar teori ini maka semakin dewasa, proses pemilihan pekerjaan semakin meningkat ke arah yang lebih realistik. Sedangkan elemen iversibilitas merujuk pada pernyataan bahwa pilihan pekerjaan itu tidak dapat diubah, dibatalkan, atau dibalikkan. Sedang elemen kompromi menyatakan bahwa pilihan pekerjaan merupakan kompromi dari faktor-faktor yang ada, antara kepentingan subyek dengan kepentingan nilai.

\section{Teori Perkembangan}

Teori ini memandang bahwa perencanaan karir merupakan perkembangan karir pada seseorang sebagai aspek perkembangan totalitas pribadi. Sebagaimana aspek perkembangan yang lain, perkembangan jabatan berlangsung mulai sejak awal kehidupan dan berlangsung secara terus menerus secara kontinum sampai akhir hayatnya. Salah satu tokoh teori perkembangan adalah Donald E. Super. Menurutnya, bekerja merupakan perwujudan konsep diri yang berlangsung sepanjang hayat, dimulai sejak awal kehidupan sampai akhir kehidupan. Dalam kaitannya dengan kerja, konsep diri tersebut berkembang melalui beberapa tahapan yang masingmasing tahap dituntut mampu menguasi tugas-tugas yang secara meningkat semakin sulit. Tahapan-tahapan tersebut adalah: (1) pertumbuhan (growth), tahap pembentukan konsep diri melalui identifikasi, (2) eksplorasi (exploration), tahap pembentukan konsep diri melalui kontak dengan orang lain dan lingkungannya, (3) Pemantapan (establisment), tahap penemuan konsep diri kerja secara mantap, sehingga tidak mungkin pindah tetapi justru ingin mengembangkannya, (4) Pembinaan (maintenance), pada tahap ini biasanya sudah mencapai sukses, dan mulai memikirkan pensiun, dan (5) penurunan (decline), yaitu tahap pengurangan kegiatan.

Pengaruh konsep diri terhadap pilihan pekerjaan, juga mengandung tiga elemen dasar, yaitu (1) formasi, yaitu pembentukan konsep diri yang didalamnya terdapat eksplorasi, 
deferensiasi diri, dan identifikasi diri, (2) translasi, yaitu penerjemahan konsep diri terhadap kerja berdasar tilikan diri dan arah jabatan, dan (3) implementasi, yaitu penerapan konsep diri terhadap pekerjaan melalui latihan. Jadi menurut Super, pilihan kerja merupakan fungsi tahap perkembangan yang berlangsung dalam rangka melaksanakan tugas-tugas perkembangan. Secara hirarkis tugastugas perkembangan tersebut adalah preferensi pekerjaan, spefifikasi preferensi, implementasi, preferensi, stabilisasi, dan konsolidasi. Untuk mendukung teorinya, selanjutnya Super mengajukan dua belas proposisi yang berkaitan dengan pekerjaan yang berlangsung sepanjang hayat.

\section{Teori Kepribadian}

Dalam teori ini memandang bahwa pilihan jabatan/pekerjaan merupakan ekspresi dari kepribadian. Dinyatakan bahwa perilaku mencari pekerjaan hakekatnya adalah upaya mencocokkan antara karakteristik individu dengan lapangan pekerjaan khusus.

Salah satu tokoh dalam teori ini adalah Holland. Dalam teorinya, Holland berusaha menjelaskan pilihan kerja berdasarkan pada tiga sudut pandang, yaitu: (1) lingkungan kerja, (2) pribadi dan perkembangannya, dan (3) interaksi pribadi dan lingkungannya. Pilihan pekerjaan merupakan perluasan kepribadian dan merupakan usaha untuk mengungkapkan diri dalam lingkungan kerja. Pilihan pekerjaan sendiri pada hakekatnya merupakan hasil interaksi antara diri dengan kekuatan-kekuatan lingkungan.

Menurut Holland, pekerjaan di masyarakat dapat dogolongkan menjadi lingkungan realistik, intelektual, sosial, dan konvensional. Sedangkan kepribadian terbagi dalam enam golongan, yaitu intelektual, realistik, sosial, konvensional, enterpise, dan artistik. Sementara aspek lingkungan dikuasai oleh pribadi terentu dan dicirikan berdasarkan orang-orang yang ada di dalamnya. Lingkungan sekaligus menggambarkan orang-orang yang ada didalamnya.Berdasarkan hal tersebut, orang cenderung mencari lingkungan yang memungkinkan ia dapat mewujudkan dirinya sesuai dengan kepribadiannya, kepribadian juga sekaligus menggambarkan bagaimana orang menyalurkan pilihan-pilihan pekerjaannya. Karena itu tingkah laku orang ditentukan oleh interaksi antara kepribadian dan lingkungan.

Tokoh lain yang termasuk dalam teori ini adalah A. Roe. Teori A Roe dikembangkan atas dasar teori 
kepribadian, dengan menempatkan faktor kebutuhan sebagai faktor penentu atas pilihan kerja. Orang memilih pekerjaan tertentu kalau pekerjaan tersebut dapat memberikan memuaskan kebutuhannya. Menurut A. Roe, sekalipun keputusan dan pilihan jabatan ditentukan sesudah masa dewasa, tetapi sangat ditentukan oleh pengalamannya pada masa kecil dalam keluarga, terutama pola asuh dan iklim yang berkembang dalam keluarga. Dikatakan bahwa pengalaman masa kecil akan menghasilkan dua orientasi pilihan pekerjaan, yaitu yang berkaitan dengan orang (misal jasa) dan bukan orang (misal teknik). Ada kecenderungan anak pola asuh yang memberikan kepuasan psikologis akan menentukan pilihan pekerjaan yang berkaitan dengan orang, dan sebaliknya.

Disamping Holland dan A. Roe, termasuk tokoh dalam teori ini adalah Williamson. Dalam pandangan Williamson, setiap orang mempunyai susunan sifat atau ciri psikologis pribadi (trait) yang khas yang hampir tidak mengalami perubahan, terutama sesudah masa remaja dan dapat diprofilkan atau dipetakan terutama berdasar tes, demikian juga dengan dunia kerja. Berdasar ini maka tugas konselor adalah membantu membuat keputusan tentang pilihan pekerjaan dengan cara mencocokkan antara trait siswa dengan persyaratan-persyaratan dunia pekerjaan. Pencocokan ini tidak hanya berdasar pada semata-mata kemampuan, bakat dan minat (trait) seperti yang diungkap dari tes, tetapi juga harus mempertimbangkan kompleksitas nilai-nilai yang telah diinternalisasikan dalam dirinya. Pencocokan tersebut berangkat dari asumsi bahwa ciri psikologis tertentu memiliki kecocokan dengan jenis pekerjaan tertentu.

\section{Teori Sosiologi}

Menurut Osipow teori ini secara fundamental didasarkan kepada pemikiran bahwa elemen-elemen di luar individu memiliki pengaruh kuat terhadap individu dalam sepanjang hidupnya, termasuk pendidikan dan keputusaan pekerjaan. Para pendukung teori ini juga berpandangan bahwa derajat kebebasan individu dalam pilihan pekerjaan/jabatan adalah jauh dari apa yang semula diasumsikan dan harapan diri seseorang tidaklah bebas dari harapan masyarakatnya. Sebaliknya, masyarakat menyajikan peluang pekerjaan /jabatan dalam suatu pola-pola yang berhubungan dengan keanggotaan kelas sosial. Berkaitan dengan kelas social dan perkembangan karir, Lipsett menyatakan bahwa keanggotaan kelas social berpengaruh terhadap pilihhan karir 
tertentu ketika ia mencapai usia remaja. Sejalan dengan itu Sewell dan Shah juga menyatakan bahwa walaupun tahapan dalam pengambilan keputusan pendidikan - karir secara mendasar tidak berbeda dari kelas ke kelas, namun waktu dan pilihannya tampaknya berbeda. Pada remaja dari kelas social yang lebih rendah, disamping pengambilan keputusan dilakukan pada usia yang lebih muda, pilihan karirnya juga berbeda, dibandingkan dengan kelas social yang lebih tinggi.

\section{Sedangkan menurut Gibson dan}

Mitchell bahwa pilihan karir lebih berhubungan dengan kesempatan dari pada sesuatu yang sengaja direncanakan. Kesempatan tersebut salah satunya dipengaruhi oleh kelas social, disamping factor-faktor lain seperti budaya, kondisikondisi yang dibawa sejak lahir atau muncul kemudian, kesempatan pendidikan, dan observasi terhadap model.

\section{Teori Ekonomi}

Menurut Gibson dan Mitchell teori ini menekankan pentingnya factorfaktor ekonomi dalam pilihan karir. Hal ini terutama terkait dengan tersedianya beberapa tipe pekerjaan versus tersedianya pekerja-pekerja yang qualified untuk pekerjaan tersebut. Faktor utama dalam pilihan karir adalah : "Apa jenis pekerjaan yang dapat saya peroleh?". Pilihan karir terutama berdasar kepada pertimbangan apakah pekerjaan tersebut dapat memenuhi kebutuhan dasar diri sendiri dan keluarganya, keamanan pekerjaan, keuntungan (khususnya asuransi kesehatan serta rencana pensiun) atau factor-faktor yang dianggap paling menguntungkan dan paling bernilai pada individu tersebut (tidak selalu dalam bentuk uang).

\section{Teori lain}

Termasuk dalam teori lain ini adalah teori belajar social. Teori ini bermaksud menjawab pertanyaan mengapa seseorang memasuki lapangan pekerjaan tertentu dan mengapa orang memperlihatkan preferensi kerja tertentu. Salah satu tokoh dalam teori ini adalah Krumboltz yang mengembangkan teori karirnya berdasar atas teori belajar sosial dari Bandura dan dikenal sebagai teori pengambilan keputusan. Menurutnya pribadi dan lingkungan merupakan faktor penting bagi penentuan keputusan karir seseorang. Pengambilan keputusan karir juga tidak berlangsung secara kebetulan, tetapi ditentukan pandangan dirinya sebagai hasil interaksi antara diri dan lingkungan tersebut, melalui pengalaman, respon-respon kognitif dan perasaan, 
serta keterampilan dalam membuat keputusan.

Menurut Munandir faktor pribadi berkenaan dengan apa yang sudah ada pada diri seseorang, seperti jenis kelamin, rupa, atau tampakan fisik dan kemampuan-kemampuan yang mengandung unsur bawaan. Sedangkan termasuk dalam pengertian lingkungan, seperti lingkungan kerja, pasar kerja, syarat kerja, pengaturan dan undangundang kerja, serta hal-hal lain di dalam masyarakat yang berpengaruh terhadap kehidupan kerja.

\section{Implikasi Teori terhadap Bimbingan dan} Konseling Karir

Menurut Sunardi ${ }^{32}$ pada dasarnya teori perkembangan karir tertentu berimplikasi pada tuntutan yang tertentu pula terhadap bagaimana dan apa yang harus dilakukan oleh konselor dalam proses konseling karir. Secara umum, implikasi teori karir terhadap bimbingan dan konseling karir dijelaskan Sunardi dengan mengutip pendapat Gibson dan Mitchell dimana mereka menjelaskan beberapa implikasi teori karir terhadap konseling karir, yaitu pentingnya konselor untuk: (1) memahami proses dan karakteristik perkembangan manusia termasuk kesiapannya untuk belajar dan keberhasilan dalam melaksanakan tugastugas tertentu sesuai dengan tahapan perkembangannya;

(2) memahami kebutuhan dasar manusia, termasuk kebutuhan khususnya dan hubungannya dengan perkembangan karir dan pengambilan keputusan; (3) dapat melakukan assesmen dan menginterpretasikan sifat-sifat individual dan karakteristiknya, serta menerapkannya dalam relasi konseling yang bervariasi; (4) memahami dan mampu membantu klien dalam memahami bahwa faktor-faktor perubahan atau faktor-faktor yang tak terduga dapat mengubah perencanaan karir; (5) memahami perubahan cepat yang terjadi dalam dunia kerja dan kehidupan,sehingga memerlukan pengujian secara tetap serta perlunya penggunaan teori dan riset-riset mutahir sebagai dasar pelaksanaan konseling.

Selanjutnya, Sunardi menjelaskan lagi bahwa peran apa yang dapat dilakukan pembimbing atau konselor karir sangat tergantung pada fokus bimbingan/konseling karir yang dihadapinya. Secara garis besar peran tersebut adalah : (1) membantu membuat keputusan-keputusan karir dengan jalan memberikan informasi yang diperlukan; (2) membantu membuat keputusan karir dengan jalan mengembangkan keterampilan membuat keputusan,; 
membantu membuat beberapa keputusan karir (bukan satu) yang saling berkaitan, dan (4) membantu memahami dan mengembangkan sifat-sifat yang dimiliki untuk mencapai keputusan karir yang telah dibuatnya. Dalam point ke empat inilah pembimbing/konselor dapat memasukkan persepktif gender dalam pemilhan karir.

$$
\text { Sejalan dengan peran }
$$
pembimbing atau konselor di atas, maka dalam konteks bimbingan dan konseling karir di sekolah, Sunardi menyarankan program bimbingan dan konseling karir seyogyanya menekankan pada:

Pertama, kemampuan memahami dan menerima diri terhadap kemampuan, bakat, minat, serta kemampuan dalam memahami dan menyesuaikan diri dengan dunia kerja. Untuk kepentingan ini diperlukan pengumpalan data dan keterangan diri melalui layanan inventarisasi pribadi dengan berbagai teknik dan cara, baik melalui tes maupun nontes.

Kedua, Tersedianya keragaman dan keluasan informasi karir yang sejalan dengan kemampuan, bakat, dan minat anak, persyaratan-persyaratan minimal yang harus dipenuhi, tuntutan aktivitas suatu jabatan, dan nilai-nilai dari jabatan tersebut. Keluasan informasi yang diberikan melalui layanan informasi karir terutama diperlukan untuk pemahaman terhadap dunia pekerjaan yang terus berubah dan berkembang secara cepat, sehingga mampu mengambil keputusan yang tepat sesuai dengan keadaan diri maupun tuntutan masyarakat. Infromasi jabatan yang diberikan seharusnya menyangkut informasi yang bersifat kuantitatif maupun kualitatif secar utuh, dan agar betul-betul dapat digunakan sebagai dasar pengambilan keputusan karir. Untuk itu, informasi tersebut harus akurat, cermat, baru, luas, dan komprehensif dengan mempertimbangkan ketersediaannya, bebas prasangka, serta bersumber pada yang berwenang. Misalnya dari Depnaker dengan Klasifikasi Jabatan Indonesia yang telah dikeluarkannya atau berdasar Kamus Jabatan Nasional. Pemberian informasi karir tersebut harus menjadi bagian terpadu dari bimbingan atau konseling yang dilakukan menuju pengambilan keputusan karir, dan dihindari kesan mengarahkan. Dengan demikian, siswa atau klien merasa dilibatkan secara penuh, baik pikiran, perasaan, maupun dalam memberikan makna terhadap pekerjaan yang sengaja dipilihnya, sehingga dapat lebih bertanggungjawab atas keputusannya.

Ketiga, kemampuan anak secara dini untuk sedini mungkin merencanakan dan mempersiapkan diri dan memperjuangkannya secara sungguh- 
sungguh dan konsisten. Setelah anak mengambil keputusan karir, maka saat itu juga sudah harus mempersiapkan diri secara matang upaya-upaya untuk mencapainya. Berkaitan dengan ini, maka pembuatan rencana kehidupan jangka pendek dan jangka panjang sangat diperlukan, terutama berkaitan dengan bagaimana memperjuangkannya dan melalui jalur mana yang harus ditempuh, serta persiapan-persiapan diri apa yang harus dikuasai.

Keempat, kemampuan untuk merasa aman, puas, dan bahagia dengan pilihan dan keputusan karir yang telah ditetapkannya. Untuk itu, keputusan pilihan karir harus terus dimantapkan, dibantu dalam memperjuangkannya,dan terus dievaluasi kemajuannya.

Untuk menunjang keberhasilan pelaksanaan program bimbingan karir, menurut Munandir, 1996 dalam (Sunardi ) beberapa program kegiatan yang perlu dilakukan sekolah adalah adalah: (1) inventarisasi pribadi, melalui kegiatan assesmen, (2) pemahaman dunia kerja, melalui layanan informasi karir, (3) orientasi dunia kerja, melalui orientasi ke lapangan, (4) konseling dan pengambilan keputusan karir, dan (4) penempatan, dan (6) tindak lanjut. (Munandir, 1996). Sementara itu, Gibson dan Mitchell Dalam (sunardi )megajukan beberapa prinsip dalam bimbingan karir yang berkaitan dengan program pemberikan kesempatan perkembangan karir menuju tercapainya putusan karir secara tepat, yaitu (1) siswa harus diberi kesempatan untuk mengembangkan suatu yang tidak bias berdasarklan putusan karirnya; (2) sejak awal dan seterusnya, perlu dikembangkan sikap positif terhadap pendidikan; siswa harus diajar untuk memandang karir sebagai suatu jalan hidup dan pendidikan sebagai persiapan untuk hidup4 (4) siswa harus dibantu untuk menghubungkan antara perkembangan sosial pribadi dengan perencanaan karir; (5) semua tingkatan siswa harus diberi pemahaman tentang hubungan antara pendidikan dan karir; (6) siswa dalam setiap jenjang pendidikannya harus mengalami orientasi karir yang sesuai dengan tingkat kesiapannya dan realistis; (g) siswa diberi kesempatan untuk menguji konsep, keetrampilan, dan peran untuk mengembangkan nilai yang digunakan untuk menentukan karir masa depannya; (h) program bimbigan karir dipusatkan di kelas, melalui koordinasi dan konsultasi dengan konselor sekolah, orang tua, sumber, dan masyarakat; (7) program bimbingan/konseling karir di sekolah harus diintegrasikan dalam fungsi bimbingan dan konseling dan program pendidikan secara utuh.

Secara teknis, pelaksanaan bimbingan karir dapat dilakukan melalui 
berbagai cara, mulai dari mengarang, wawancara imajinatif dengan tokoh yang dikagumi, sampai pada penggunaan komputer. Berkaitan dengan pemanfaatan komputer Gibson dan Mitchell maupun Milgram dalam Sunardi mencatat bahwa penggunaan komputer ternyata memberikan sumbangan yang signifikan bagi perkembangan karir individu. Sedangkan settingnya dapat dilakukan secara individual ataupun kelompok, menyesuaiakn dengan kebutuhan. Secara khusus Gibson dan Mitchell menjelaskan bahwa dalam pengembanagn karir, yang berakhir pada penempatan, maka konselor dapat menggunakan beberapa teknik, yaitu (1) kesadaran diri (selfawareness). Sejak dini seseorang harus sadar dan menghargai keunikan dirinya sebagai manusia. Pemahaman tentang bakat, minat, nilai, sifat pribadi, dsb sangat penting dalam perkembangan konsep yang berhubungan dirinya sendiri dan eksplorasi karir. Caranya dengan latihan klarifikasi, mengarang, penggunaan film, tes, dsb; (2) kesadaran pendidikan (educational awareness). Kesadaran hubungan antara diri sendiri, kesempatan pendidikan, dan dunia kerja sangat penting dalam perencanaan karir. Salah satu caranya dapat dengan menghadirkan alumni; (3)kesadaran karir (career awareness). Pada semua tingkatan pendidikan, konselor sekolah harus mampu membantu siswa untuk terus meluaskan ilmu pengetahuan atau wawasan dan kesadaran akan dunia kerja. Termasuk pengembangan pemahaman hubungan antara nilai, gaya hidup, dan karir; (4)eksplorasi karir (career exploration). Agar eksplorasi karir dapat berjalan ke arah yang lebih sistematis, maka diperlukan perencanaan dan analisis karir sesuai dengan minatnya. Bila dilakukan melalui studi banding, pengetesan realita, dan sebagainya; (5)perencanaan karir dan pembuatan keputusan (career planing and decision making). Pada akhirnya pilihan karir siswa lebih terfokus, menyempit, atau terspesialisasi, dan perencanaan karir dimaksudkan untuk menguji secara kritis keputusan yang diambilnya.

ABKIN dan ILO33 menyebutkan bahwa bimbingan karir di sekolah diberikan kepada peserta didik sebagai bagian dari proses yang partisipatif dan berpusat pada peserta didik. Peran dari guru BK adalah tidak untuk mendikte pilihan peserta didik, namun memandu dan memfasilitasi mereka melalui proses pengambilan keputusan dan memberikan ruang bagi mereka dalam melihat secara kritis apa saja potensi, kesempatan pekerjaan dan jalur pendidikan yang bisa mereka ambili34.Proses pengambilan keputusan yang baik akan terjadi apa bila pilihan karir tidak dibatasi terutama oleh 
pandangan streotip gender yang berkembang di tengah masyarakat dimana masyarakat masih melihat sebuah pekerjaan sesuai tidaknya berdasarkan gender. Dalam hal ini perpspektif gender harus ada dalam materi bimbingan dan konseling karir terkait bias gender dalam pekerjaan.

Selanjutnya ABKIN dan ILO menyebutkan dalam implementasi bimbingan dan konseling karir di sekolah, siswa harus diberi pemahaman bahwa bias gender itu ada di dalam masyarakat terkait dengan hukum alam dan peran dengan cara memberikan kompetensi kepada siswa untuk dapat membedakan antara karakter dan peran. Setelah siswa memiliki kompetensi untuk membedakan antara karakter dan peran, siswa juga harus dibekali dengan kompetensi untuk menilai apakah sebuah pekerjaan itu merupakan pekerjaan laki-laki atau perempuan atau pekerjaan tersebut untuk laki-laki dan perempuan ${ }^{35}$

\section{METODE}

Subyek penelitian adalah 50 siswi di Madrasah Aliyah Dinyah Puteri Pekanbaru Riau, dua Guru BK/Konselor, kepala madrasah dan waka kurikulum. Pengumpulan data dengan kuesioner tertutup yang terdiri dari pertanyaan: (1) karakter dan peran laki-laki dan perempuan dalam masyarakat, (2) karir yang sesuai untuk perempuan dan lakilaki, dan wawancara pada Guru BK/Konselor serta kepala madrasah dan waka kurikulum mengenai pelaksanaan bimbingan karir.

\section{PEMBAHASAN}

\section{Pengetahuan siswa mengenai karakter dan peran laki-laki dan perempuan}

Hasil penelitian menunjukkan bahwa $60 \%$ dari total responden mengatakan bahwa maskulin, emosional, rasional, menarik, berani, hati-hati, modis, kasar, kuat adalah karakter pria dan wanita. $100 \%$ dari total responden mengatakan bahwa menyusui dan melahirkan adalah peran perempuan. Memasak, mengasuh anak, mencari nafkah, memimpin keluarga, sekretaris, mengelola uang bisa menjadi peran lakilaki dan perempuan, ditunjukkan oleh $85 \%$ dari total responden. Ini berarti bahwa responden tahu bahwa laki-laki dan perempuan tidak bisa dibedakan melalui karakter dan peran.

\section{Karir pilih siswa jika sudah tamat sekolah}

$$
2 \% \text { dari total responden }
$$
mengatakan karir yang mereka inginkan adalah karir yang dianggap sebagai karir 
maskulin seperti penambang, operator alat berat dan mekanik. 98\% dari total responden menginkan karir yang dianggap sebagai feminin seperti perawat, bidan, desainer, stylist, guru, teller bank. Alasan untuk memilih karir yang anggap sebagai maskulin adalah saya suka karir ini dan karir ini tepat untuk pria dan wanita. Alasan memilih karir yang anggap feminin adalah saya suka karir ini dan karir ini sesuai untuk laki-laki dan perempuan. Ini berarti bahwa responden tidak berpandangan stereotipe gender mengenai karir yang akan mereka pilih.

\section{Proses siswi mengetahui bahwa laki-laki} dan perempuan tidak bisa dibedakan melalui karakter dan peran.

$70 \%$ dari total siswa menjawab mereka mengetahui bahwa laki-laki dan perempuan tidak dapat dibedakan melalui karakter dan peran ketika mendapat materi tentang gender dalam layanan informasi karir yang diberikan oleh guru BK/Konselor. Hal ini juga didukung dari hasil wawancara dan observasi yang dilakukan terhadap guru BK/Konselor, waka kurikulum dan kepala madrasah dan implementasi bimbingan daan konseling karir.

Menurut Guru BK/Konselor, bimbingan dan konseling karir harus mampu membantu peserta didik dalam membuat keputusan yang menyangkut pendidikan dan pekerjaan yang sesuai dengan kemampuan, dan permintaan pasar kerja. Kerangka kegiatan dan rencana layanan harus mengarah pada proses pengambilan keputuan. Kerangka ini mengacu pada Panduan Pelayanan Bimbingan Karir, ABKIN, ILO, 2011 yang ditunjukkan dalam lima fokus utama layanan yang dijabarkan dalam:

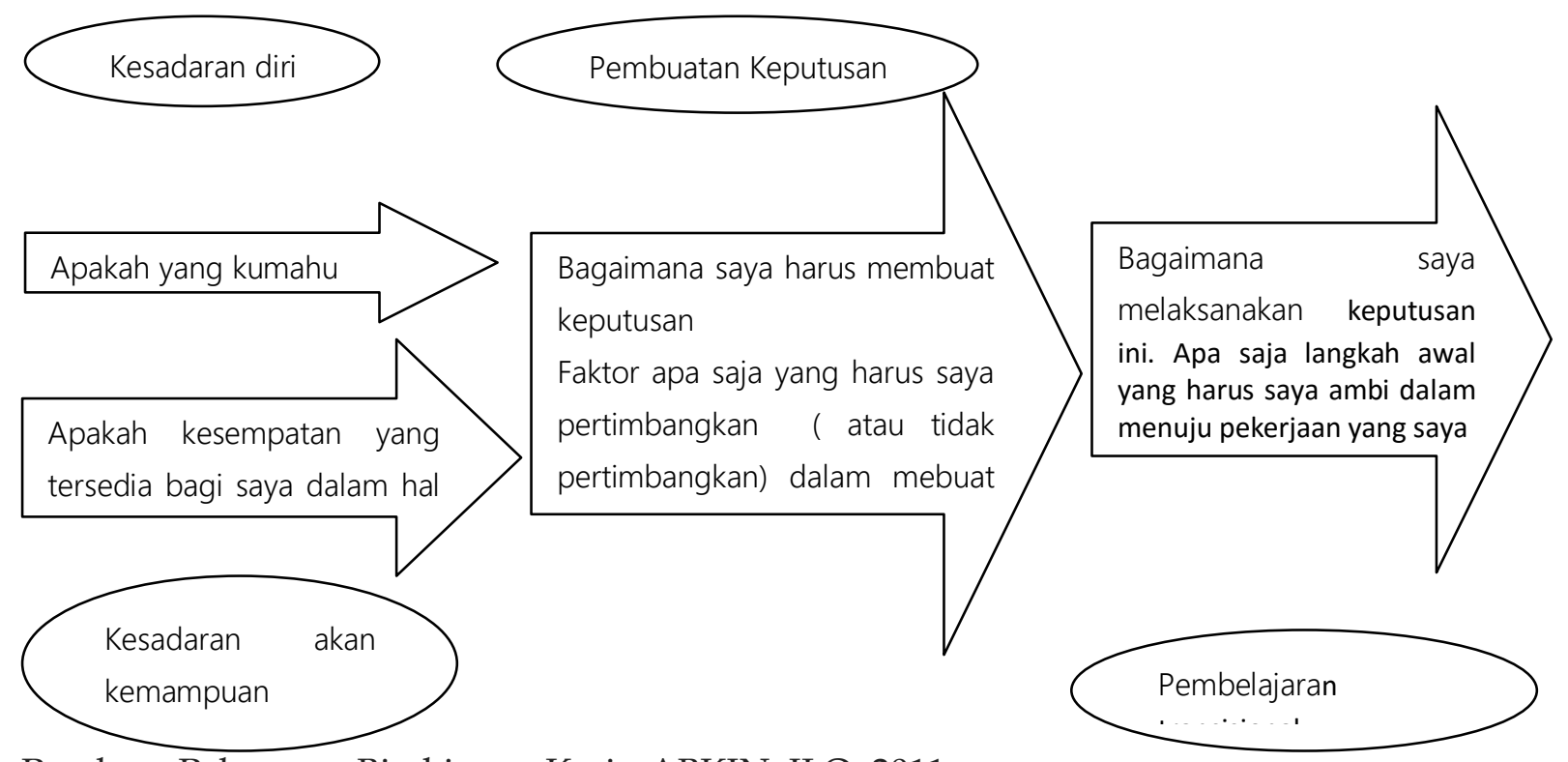

Panduan Pelayanan Bimbingan Karir, ABKIN, ILO, 2011 
Dalam layanan pengenalan diri ada delapan materi yang dibahas, yaitu kenali dirimu sendiri, mari cari tahu hal yang penting bagimu, pertimbangkan kemampuan akademismu, jenis keterampilan yang sesuai untukku, kondisi kerja yang kusuka, dukungan keluargaku, menyadari adanya bias gender di masyarakat terkait dengan hukum alam dan pekerjaan laki-laki dan perempuan. Tujuan materi menyadari adanya bias gender di masyarakat terkait dengan hukum alam dan peran adalah agar siswa memahami perbedaan / pemisahan gender dalam keterampilan kerja. Dan tujuan materi pekerjaan lakilaki dan perempuan adalah agar siswa memahami isu gender dalam pekerjaan. Kedua materi ini diberikan dalam satu jam pembelajaran (45menit) dalam bentuk kegiatan klasikal dan diskusi kelompok.

Ada tiga tahapan kegiatan dalam menyampaikan materi menyadari adanya bias gender di masyarakat terkait dengan hukum alam peran serata pekerjaan lakilaki dan perempuan. Tahapan tersebut meliputi tahap pembukaan, utama dan penutup.

Tahap pembukaan pada materi menyadari adanya bias gender di masyarakat terkait dengan hukum alam dan peran diawali dengan penjelasan bahwa kebudayaan sebuah masyarakat mempertalikan peran kepada perempuan dan laki-laki di luar fungsi biologis mereka yang telah ditetapkan, dan peran peran ini terkadang membatasi pilihanpilihan pekerjaan dan pendidikan seseorang. Hal ini perlu diatasi karena (a) hal tersebut merupakan pembatasan terhadap hak-hak seseorang, dan (b) hal tersebut menghalangi masyarakat untuk mempergunakan bakat-bakat anggotanya dengan sebaik mungkin. Lebih jauh, Guru BK/Konselor menjelaskan hal-hal berikut: Laki-laki dan perempuan dapat dibedakan secara eksklusif oleh karakteristik yang berhubungan dengan kegiatan reproduktif yang hanya dapat dilakukan oleh seorang perempuan. Gender berhubungan dengan karakteristik dan peran yang dianggap berasal dari sesorang oleh masyarakat/komunitas tertentu. Dalam masyarakat tradisional contohnya, perempuan perempuan diasosiasikan dengan kegiatan-kegiatanrumah tangga seperti memasak, mengasuh anak, menyiapkan makanan, atau menyapu rumah. Di sisi lain, laki-laki diasosiasikan dengan kegiatan kegiatan yang berkaitan dengan perlindungan keluarga dan kebutuhan-kebutuhan ekonomi. Kegiatankegiatan seperti bekerja untuk mendapatkan uang atau membuat keputusan lebih sering diasosiasikan dengan laki-laki. Dalam dunia kerja, orang mungkin merasa dibatasi dalam 
pilihan-pilihan mereka karena peran/karakteristik gender dalam masyarakat yang yang telah ditugaskan kepada mereka.

Tahapan utama, Guru BK/Konselor membagi kelas ke dalam kelompok dan membagikan Lembar Kerja kepada masing-masing kelompok. Masing-masing kelompok diminta untuk mengidentifikasi apakah pekerjaan yang ada di dalam Lembar Kerja sesuai untuk laki-laki dan perempuan, serta menjelaskan alasannya. Jawabannya kemudian dituliskan pada kertas flipchart. Masing-masing kelompok memaparkan hasil diskusi mereka.

Tahapan penutup: ketika semua prasangka telah dikemukakan, Guru BK/Konselor menekankan bahwa: (1) perempuan telah terbukti bahwa mereka mampu menjadi pengemudi/mekanik yang hebat, dan laki-laki telah menunjukkan bahwa mereka mampu menjadi peñata rambut atau penjahit, sebagai contoh; (2) tidak ada kelompok gender yang apriori lebih cocok untuk suatu pekerjaan atau keterampilan dibandingkan dengan kelompok yang lain; (3) pilihan-pilihan kerja harus berdasarkan preferensi individual, kompetensi, dan peluang pasar, bukan berdasarkan jenis kelamin; (4) beberapa pekerjaan perlu diadaptasi untuk satu jenis kelamin atau yang lain (dalam hal kerja malam, keselamatan pekerjaan, dan perlindungan kesehatan), tapi hal itu seharusnya tidak mengecilkan hati lakilaki untuk mengambil pekerjaan yang dianggap cocok untuk perempuan, ataupun juga mengecilkan hati perempuan untuk mengambil pekerjaan yang dianggap cocok untuk laki-laki.

Guru BK/Konselor mengutip kasus dari beberapa anak perempuan yang belajar dan direkrut sebagai montir. Pengusaha/majikan bahkan lebih menghargai keterampilan mereka daripada rekan-rekan kerja laki-laki mereka, karena mereka menunjukkan keterampilan yang lebih baik dalam berurusan dengan pelanggan. Peserta didik harus bercermin pada kasus ini dan membuat pilihan keterampilan yang BENAR-BENAR mereka inginkan.

Guru BK/Konselor kemudian mengakhiri kegiatan dengan bertanya kepada peserta didik (a) apa yang mereka pikirkan tentang pembagian peran lakilaki dan perempuan berkaitan dengan pendidikan dan pekerjaan, (b) apakah mereka merasa dibatasi oleh peran-peran ini pada saat mereka membuat pilihanpilihan pendidikan, (c) apa yang hendak mereka lakukan mengenai hal itu, (d) bantuan apa yang mereka butuhkan dari Guru BK/Konselor berkaitan dengan hal ini.

Seperti penyampaian materi 
menyadari adanya bias gender di masyarakat terkait denga hukum alam dan peran, penyampaian materi pekerjaan Laki-laki atau Perempuan? Juga diajarkan dalam tiga tahapan, yaitu tahap pembukaan, utama dan penutup.

Tahapan pembukaan, Guru BK/Konselor akan melaksanakan kegiatan yang dapat meningkatkan kemampuan peserta didik untuk menentukan cita-cita mereka, terlepas dari stereotip gender tentu saja kegiatan ini dapat dilakukan setelah mendiskusikan pandangan-pandangan yang peserta didik miliki berkaitan dengan peran, gender, dan jenis pekerjaan,

Tahap utama, Guru BK/Konselor membagikan Lembar Kerja 8 (Siapakah yang tepat melakukan pekerjaan di bawah ini). Sebelumnya siswa sudah membentuk kelompok kecil dan setiap peserta didik mengidentifikasi pekerjaan mana yang lebih cocok untuk masing-masing gender dan alasan. Dengan menjawab ke-23 pertanyaan tersebut dan mengadakan diskusi terbuka tentang alasan-alasan di balik jawaban mereka, mereka akan menyadari bahwa mungkin ada pendapat-pendapat yang berbeda, dan bahwa beberapa alasan mungkin tidak sepenuhnya benar.

Penutup: Guru BK/Konselor memfasilitasi sebuah diskusi tentang manfaat dan tantangan yang terkait dengan partisipasi laki-laki dan perempuan di semua pekerjaan. Latihan ini harus mendorong peserta didik untuk membuat keputusan tentang apa yang benar-benar mereka inginkan, bukan apa yang mereka rasa harus mereka lakukan sebagai perempuan atau laki-laki. Guru $\mathrm{BK} /$ Konselor mengakhiri kegiatan dengan bertanya kepada peserta didik (a) apa yang mereka pikirkan tentang pentingnya partisipasi yang setara antara laki-laki dan perempuan dalam dunia kerja, (b) apakah mereka merasa telah ada kemajuan dalam masyarakat mereka menuju ke arah tersebut, (c) apa yang akan mereka lakukan untuk mempromosikannya, (d) bantuan apa yang mereka butuhkan dari Guru BK/Konselor berkaitan dengan hal ini.

Dari hasil penelitian yang sudah dipaparkan dapat disimpulkan bahwa dalam menyampaikan materi bimbingan dan konseling karir Guru BK/Konselor menggunakan pendekatan layanan aktif dimana guru BK adalah tidak mendikte pilihan peserta didik, namun memandu dan memfasilitasi mereka melalui proses pengambilan keputusan dan memberikan ruang bagi mereka dalam melihat secara kritis apa saja potensi, kesempatan pekerjaan dan jalur pendidikan yang bisa mereka ambil tanpa membeda-bedakan antara pekerjaan laki-laki dan perempuan. Hal ini sangat mempengaruhi siswa 
dalam membuat pilihan karir mereka kedepan. Dengan demikian, dapat disimpulkan bahwa streotip gender dalampilihan karir siswa dapat dikurangi walaupun siswa belajar di sebuah lembaga pendidikanyang selalu dikonotasikan dengan penyumbang bias gender dalam pendidikan.

\section{KESIMPULAN DAN SARAN}

Karir adalah suatu status atau jenjang pekerjaan atau jabatan seseorang sebagai sumber nafkah apakah itu sebagai pekerjaan utama maupun pekerjaan sambilan. Karena karir merupakan sumber nafkah maka ia selalu menjadi masalah yang kompleks, yang menyangkut berbagai aspek kehidupan, baik aspek perkembangan, kepribadian, sosial, budaya, ekonomi, maupun belajar.

Begitu kompleksnya masalah karir menyebabkan siswa yang duduk dibangku SMA/MA banyak yang bingung dalam pemilihan karir mereka setelah menamatkan pendidikan di jenjang SLTA. Faktor streotip gender merupakan salah satu faktor yang mempengaruhi pemilihan karir siswa. Oleh karena itu, bimbingan dan konseling karir di sekolah/madrasah haruslah memberi arah sekaligus penerang jalan hidup menuju keberhasilan dan kepuasan dalam mengarungi kehidupan.
Mengingat

pentingnya

bimbingan dan konseling karir sebagai pemberi arah sekaligus penerang jalan hidup, maka dalam pelaksanaannya hendaklah mampu membantu siswa dalam: (a) pemahaman secara tepat tentang dirinya, dalam hal ini siswa diperkenalkan dengan streotif gender dalam karir; (b) pengenalan terhadap keragaman dunia kerja dan persyaratannya; (c) mempersiapkan diri secara matang dalam memasuki dunia kerja; (d) penempatan bidang-bidang pekerjaan tertentu yang sesuai; (e) memecahkan berbagai persoalan khusus berkaitan dengan pekerjaan dan pola-pola kehidupan yang lain, dan (f) penghargaan yang obyektif dan sehat terhadap pekerjaan, jabatan, serta karir. Selanjutnya, mengingat semakin luasnya bidang pekerjaan saat ini, pelaksanaan bimbingan/konseling karir dituntut mampu merangsang tumbuh dan berkembangnya pemikiran-pemikiran di bidang pekerjaan yang sifatnya lebih kreatif, imajinatif, dan holistik, sehingga perkembangan, pola, atau pandangan karirnya tidak linier, namun lebih menyebar, terdeferensiasi, dan terspesifikasi sesuai dengan kebutuhan dan tantangan jaman.Untuk itu bimbingan dan konseling karir berperspektif gender sangat perlu diimplementasikan dan diperluas 
cakupan implementasinya pada setiap jenjang pendidikan, baik di sekolah maupun madrasah.

\section{Endnotes:}

1 Bandura, A., Barbaranelli, C., Caprara, G. V., \& Pastorelli, C. (2001). Self- efficacy Beliefs as shapers of children's aspirations and career trajectories. Child Development, 72 (1), 187-206.

2 Cherian VI 1991. Parental aspirations and academic achievement of Xhosa children. Psychological Reports, 68: 547-553.

3 Issa AO, Nwalo KIN 2008. Factors Affecting the Career Choice of Undergraduates in Nigerian Library and Information Science Schools. African Journalof Library, Archives and Information Science. From http://findarticles.com/p/articles_7002 1_18/ai_n28539226/?tag= content; coll

4 Macgregor K 2007. South Africa: Student Dropout Rates Alarming in SA Universities. From http://www. universityworldnews.com/article.php? story $=200710251025102245380$ (Retrieved on 23 November 2011).

5 McMahon M, Watson M 2005. Occupational information: What children want to know? Journal of Career Development, 31: 239-249Savickas, M, \& Lent, R. (1994). Convergence in Career Development; Theories. Palo Alto, California: Consulting Psychologists press, Inc

6 Watson M, McMahon M, Foxcroft C, Els C 2010. Occupational aspirations of low socio economic Black South African children. Journal of Career Development, 37(4): 717-734. doi:10.1177/089 48 45309359351

7 Kinanee, J. B. (2004). The youth and career development. Port Harcourt; Kench Resources. Page. 86

8 Hurlock, E.B. (1990). Psikologi Perkembangan Suatu Pendekatan
Sepanjang Rentang Kehidupan. Jakarta : Erlangga.hal 207

9 Mamat Supriatna.2009, Layanan Bimbingan Karir di Sekolah Menengah, Departemen Pendidikan Nasional Universitas Pendidikan Indonesia.hal 7

10 Yusuf LN, \& Juntika Nurihsan, (2008), Landasan Bimbingan dan Konseling, Bandung :Program Pasca Sarjana Universitas Pendidikan Indonesia \& Remaja Rosda Karya.hal 56

11 Yusuf LN, \& Juntika Nurihsan, (2008), Landasan Bimbingan dan Konseling, Bandung :rogram Pasca Sarjana Universitas Pendidikan Indonesia \& Remaja Rosda Karya.hal 58

12 Brown, C. And M. Corcoran. 1997. Sex Based Deferences In School Content and The Male-Female Wage Gap." Journal Of Labor Economics 15 (3):431\{465.

13 Holland, J. L. (1997). Making Vocational Choices: A Theory of Vocational Personalities Work Environments. Odessa, FL: Psychological Assessment Resources, Inc.Page 234

14 R.W.,Brown, S. D., \& Hacket, G.(1996) "Career Development from Sociocognitive Perspective" in D., Brown \& L., Brooks (eds) Career Choice and Development (3rd ed.) San Francisco: Jossey -Bass.Page234

15 Oktiva Herry Chandra prints. undip.ac.id/36914/

16 Oktiva Herry Chandra eprints. undip.ac.id/36914/

17 ABKIN dan ILO, Modul Panduan Pelayanan Bimbingan Karir, 2011, hal.22)

18 http://repository.usu.ac .id/bitstream /123456789/28459/2/Chapter\%20III.pdf

19 http://repository.usu.ac.id / bit stream/ 23456789/28459/2/ Chapter\%20III.pdf

20 http://kbbi.web.id/stereotip 
Lips, Hitary M. 1988. Sex and Gender: A Introduction. Catifornia: Mayfietd Pubtishing Co.page 86

22 Oktiva Herry Chandra eprints. undip.ac.id /36914/

23 Oktiva Herry Chandra eprints. undip.ac.id /36914/

24 Oktiva Herry Chandra eprints.undip .ac.id /36914/

Oktiva $\quad$ Herry $\quad$ Chandra
eprints.undip.ac.id /36914/

26 Dewa Ketut Sukardi. 1987. Bimbingan karir di sekolah-sekolah : Jakarta : Ghalia Indonesia. Hal.69

27 Handoko, Hani T. 2000. Manajemen Personalia dan Sumber Daya Manusia. Yogyakarta : BPFE.Hal.97

28 Gibson, R. L. dan Mitchell, M.H. 1995. Intoduction to Counseling and Guidance, Englewood Cliffs - New Jersey: PrenticeHall Inc. Herr \& Edwin.L, 1991. Career Guidance and Counseling T.Page 65

29 Gould, S. 1979, "Characteristics of Career Planners in Upwardly Mobile Occupations", Academy of Management Journal, Vol. 22, pp. 539-50. Greenhaus, J.H., Parasuraman, S.J. and Wor

30 Greenhaus, J.H., Parasuraman, S.J. and Wormley, W.M. 1990, “Effects of Race on Organizational Experiences, Job Performance Evaluations, and Career Outcomes", Academy of Management Journal, Vol. 33, pp. 64-86.

31 file.upi.edu/Direktori/FIP/...SUNARDI /.../HAKEKAT_KARIR.pdf

32 file.upi.edu/Direktori/FIP/...SUNARDI /.../ HAKEKAT_KARIR.pdf

33 ABKIN dan ILO, Modul Panduan Pelayanan Bimbingan Karir, 2011, hal.22)

34 ABKIN dan ILO, Modul Panduan Pelayanan Bimbingan Karir, 2011, hal.
35 ABKIN dan ILO, Modul Panduan Pelayanan Bimbingan Karir, 2011, hal.22)

\section{DAFTAR PUSTAKA}

ABKIN dan ILO, Modul Panduan Pelayanan Bimbingan Karir, 2011

Bandura, A., Barbaranelli, C., Caprara, G. V., \& Pastorelli, C. (2001). Selfefficacy Beliefs as shapers of children's aspirations and career trajectories. Child Development, 72 (1), 187-206

Brown, C. And M. Corcoran. 1997. Sex Based Deferences In School Content and The Male-Female Wage Gap." Journal Of Labor Economics 15 (3):431-465.

Cherian VI 1991. Parental aspirations and academic achievement of Xhosa children. Psychological Reports, 68: 547-553

Dewa Ketut Sukardi. 1987. Bimbingan karir di sekolah-sekolah : Jakarta : Ghalia Indonesia

file.upi.edu/Direktori/FIP/...SUNARDI /.../HAKEKAT_KARIR.pdf

Gibson, R. L. dan Mitchell, M.H. 1995. Intoduction to Counseling and Guidance, Englewood Cliffs - New Jersey: Prentice-Hall Inc. Herr \& Edwin.L, 1991. Career Guidance and Counseling

Gould, S. 1979, "Characteristics of Career Planners in Upwardly Mobile Occupations", Academy of Management Journal, Vol. 22, pp. 539-50 
Greenhaus, J.H., Parasuraman, S.J. and Wormley, W.M. 1990, "Effects of Race on Organizational Experiences, Job Performance Evaluations, and Career Outcomes", Academy of Management Journal, Vol. 33, pp. 64-86.

Handoko, Hani T. 2000. Manajemen Personalia dan Sumber Daya Manusia. Yogyakarta: BPFE.

Holland, J. L. (1997). Making Vocational Choices: A Theory of Vocational Personalities Work Environments. Odessa, FL: Psychological Assessment Resources, Inc.

Hurlock, E.B. (1990). Psikologi Perkembangan Suatu Pendekatan Sepanjang Rentang Kehidupan. Jakarta : Erlangga

Issa AO, Nwalo KIN 2008. Factors Affecting the Career Choice of Undergraduates in Nigerian Library and Information Science Schools. African Journalof Library, Archives and Information Science. From http:/ / findarticles.com/p/articles 7002_1_18/ai_n28539226/?tag= content; coll

Kinanee, J. B. (2004). The youth and career development. Port Harcourt; Kench Resources

Mamat Supriatna.2009, Layanan Bimbingan Karir di Sekolah Menengah, Departemen Pendidikan Nasional Universitas Pendidikan Indonesia

Macgregor K 2007. South Africa: Student Dropout Rates Alarming in SA Universities. From http://www. universityworldnews.com/article.p $\underline{\mathrm{hp}}$ ? story $=200710251025102245380$ (Retrieved on 23 November 2011).

McMahon M, Watson M 2005. Occupational information: What children want to know? Journal of Career Development, 31: 239249Savickas, M, \& Lent, R. (1994). Convergence in Career Development; Theories. Palo Alto, California: Consulting Psychologists press, Inc

Oktiva Herry Chandra eprints. undip.ac.id/36914/

R.W.,Brown, S. D., \& Hacket, G.(1996) "Career Development from Sociocognitive Perspective" in D., Brown \& L., Brooks (eds) Career Choice and Development (3rd ed.) San Francisco: Jossey -Bass.Page234

Watson M, McMahon M, Foxcroft C, Els C 2010. Occupational aspirations of low socio economic Black South African children. Journal of Career Development, 37(4): 717-734. doi:10.1177/089 4845309359351

Yusuf L.N., \& Juntika Nurihsan, (2008), Landasan Bimbingan dan Konseling, Bandung :rogram Pasca Sarjana Universitas Pendidikan Indonesia \& Remaja Rosda Karya

http://repository.usu.ac .id/bitstream L123456789/28459/2/Chapter\%20II I.pdf 